\title{
Development of a Method for Manufacturing External Quality Assessment Material for Genetic Testing of Solid Tumors Using Mutant and Wild-Type Cell Lines
}

\author{
Jinyoung Hong ${ }^{1 \oplus}$, Ji Hyun Kim ${ }^{1 \oplus}$, Seungman Park ${ }^{2 \oplus}$, Sang Gon Lee ${ }^{3 \oplus}$, Woochang Lee ${ }^{1 \oplus}$, \\ Sail Chun ${ }^{1 \oplus}$, and Won-Ki Min ${ }^{1 \oplus}$ \\ ${ }^{1}$ Department of Laboratory Medicine, Asan Medical Center, University of Ulsan College of Medicine; ${ }^{2}$ Seegene Medical Foundation, \\ Seoul; ${ }^{3}$ Laboratory Medicine, Greencross Laboratories, Yongin, Korea
}

\section{Corresponding author:}

Woochang Lee

Department of Laboratory Medicine, Asan Medical Center, University of Ulsan College of Medicine, 88 Olympic-ro 43gil, Songpa-gu, Seoul 05505, Korea Tel +82-2-3010-4506

Fax +82-2-478-0884

E-mail wlee1@amc.seoul.kr

Received: September 23, 2020 Revised: November 18, 2020 Accepted: November 29, 2020
This is an Open Access article distributed under the terms of the Creative Commons Attribution Non-Commercial License (http://creativecommons.org/licenses/ by-nc/4.0) which permits unrestricted non-commercial use, distribution, and reproduction in any medium, provided the original work is properly cited.
Background: DNA extracted from mutant cell lines is frequently used as an external quality assessment (EQA) material for genetic testing of solid tumors because it is easy to obtain. However, the proportion of mutations in cell lines is different from that in actual tumor samples. In this study, mixtures of mutant DNA and wild-type DNA mimicking patient samples were analyzed to optimize the amount of mutant DNA in EQA specimens.

Methods: Four cell lines harboring the selected mutation were cultured, and genomic DNA was extracted from cultured cells. Wild-type cell line DNA was prepared in the same manner. Diluted samples were prepared by mixing each mutant cell line DNA and wild-type cell line DNA at different ratios. Sanger sequencing of target variants was performed. For reliability, sequencing was repeated three times and read by two readers. The cutoff was based on the lowest proportion of mutant DNA that was determined to be positive in all three experiments.

Results: The cutoffs of mutant cell line DNA ratios were $10 \%, 5 \%, 25 \%$, and $25 \%$ for KRAS G12C, EGFR exon 19 deletion, EGFR T790M, and BRAF V600E, respectively. For the cell lines harboring EGFR T790M and BRAF V600E, the mutant fraction was not $100 \%$.

Conclusions: When manufacturing EQA material for solid tumor genetic testing, consistent results can be obtained if the mutant proportion is $10 \%$ or more. In addition, the mutant allele frequency of the cell line should be checked in advance to guarantee that EQA materials contain enough mutant DNA.

(Lab Med Qual Assur 2021;43:31-36)

Key Words Genetic testing, Laboratory proficiency testing, Somatic variant
서론

정밀의학(precision medicine)은 질병의 유전학적, 환경적 배 경을 이용하여 환자 개개인에 맞추어 예방, 진단, 치료를 개별화한
다. 유전적 정보를 기반으로 한 질병의 예후 예측과 특정 유전형 및 생물학적 바이오마커를 표적으로 하는 치료의 선택적인 사용은 환자의 임상결과 및 치료의 개선을 가져올 것으로 생각된다[1]. 종 양치료에서의 정밀의학은 특정한 치료제가 이득을 줄 수 있는 환 
자를 선별하거나, 특정한 치료제로 인해 심각한 부작용을 겪을 수 있는 환자들을 선별하거나, 특정 치료제에 대한 치료반응을 추적 관찰할 수 있는 동반진단(companion diagnostics)의 형태로 종 양의 유전적 정보를 사용하고 있다[2]. 현재 gefitinib과 같은 여러 표적 치료제의 도입으로[3], 종양의 검사에 있어서 병리학적, 영상 의학적 소견뿐만 아니라 환자의 종양세포에 특정 유전자 변이가 있는지 검사하는 유전학적 검사가 동반진단의 한 종류로서 임상검 사실에서 매우 빈번하게 시행되고 있다. 고형종양 유전자검사 결 과는 약제 감수성/내성에 대한 정보를 예측하거나 예후인자로 활 용되는 임상적으로 중요한 정보이므로, 이 결과가 부정확하면 환 자가 최적의 치료를 받을 수 없을 수 있으므로 반드시 신뢰할 수 있는 검사결과의 보고가 이루어져야 한다. College of American Pathologists에서 실시하는 accreditation program 및 재단법 인 진단검사의학재단에서 실시하는 우수검사실 인증심사 규정에 따르면, 고형종양 유전자검사는 반드시 외부정도관리를 실시하여 검사의 수행능을 평가하고 임상 검체를 검사하는 검사법에 대한 적절한 평가가 가능해야 한다. 외부정도관리물질은 실제 환자 검 체와의 유사성이 매우 중요하지만, 안정적인 검체 공급의 어려움, 균질성, 안정성 문제 등으로 실제 환자 검체를 외부정도관리물질 로 사용하기는 어렵다[4]. 이와 같은 이유로 현재 국내에서 고형종 양 유전자검사에 대한 외부정도관리물질 발송은 대부분 hot spot mutation을 가지는 것으로 알려진 세포주의 DNA를 이용하고 있 다. 고형종양 유전자검사는 종양세포에 존재하는 체성 변이를 검 출하는 것을 목적으로 하는데, 실제 임상 검체는 종양세포와 정상 세포가 혼재된 상태이기 때문에 유전질환과 같이 variant allele frequency가 $50 \%$ 혹은 $100 \%$ 인 상황이 아니다. 따라서 세포주 의 DNA를 그대로 외부정도관리물질로 사용할 경우, 실제 환자 검 체와는 다른 조건이 되기 때문에 임상검사실에서 사용하는 검사법 의 수행능을 적절히 평가하는 방법이라고 하기 어렵다. 이 연구에 서는 변이 DNA와 야생형 DNA가 혼합된 검체를 이용하여 실제 임 상검사실에서 사용하는 검사법이 일관성 있게 돌연변이를 검출할 수 있는 검체의 변이 세포주 DNA의 최소 희석 분율을 확인하고 이 자료를 근거로 외부정도관리물질 제조방식을 제안하고자 하였다.

\section{재료 및 방법}

\section{DNA 추출 및 희석}

체성 변이의 해석지침에 따랐을 때, Food and Drug Administration에서 승인한 표적 치료가 있거나, 전문적인 지침에 포 함되어 있거나, 해당 분야의 전문가들 사이에 일치가 있는 강력 한 연구결과가 있는 등 임상적 의의가 분명한 tier 1: variants of strong clinical significance에 속하는 KRAS G12C, EGFR exon 19 deletion, EGFR T790M, BRAF V600E의 4가지 변이를 실험 대상으로 선정하였다[1] (Table 1). 2019년 대한임상검사정도관 리협회 신빙도조사사업 고형종양 진단유전검사 프로그램에 이용 되었던, 해당 변이를 가지고 있는 상품화된 세포주 4종류를 RPMI 1640 media에 소태아혈청을 첨가한 배지에 배양하였다. 배양한 세포로부터 G-DEX IIb Genomic DNA Extraction Kit (iNtRON Biotechnology, Seongnam, Korea)를 이용하여 genomic DNA를 추출하였다. 희석 및 대조군으로 사용할 야생형 DNA를 얻기 위하여 정상 세포주를 같은 방법으로 배양하였고 genomic $\mathrm{DNA}$ 를 추출하였다. 이와 같이 추출한 변이 세포주 DNA와 야생 형 세포주 DNA를 희석비율을 달리 하여 희석 검체를 제조하였다 (Table 2).

Table 2. Ratios of mutant cell line DNA and wild-type cell line DNA of each sample

\begin{tabular}{cc}
\hline Mutant cell line DNA (\%) & Wild-type cell line DNA (\%) \\
\hline 100 & 0 \\
75 & 25 \\
50 & 50 \\
25 & 75 \\
10 & 90 \\
5 & 95 \\
0 & 100 \\
\hline
\end{tabular}

Table 1. Variants selected for the study

\begin{tabular}{lll}
\hline Gene & \multicolumn{1}{c}{ Sequence variant } & \multicolumn{1}{c}{ Amino acid change } \\
\hline KRAS & NM_004985.4:c.34G>T & NP_004976.2:p.Gly12Cys \\
EGFR & NM_005228.4:c.2236_2250del & NP_005219.2:p.Glu746_Ala750del \\
EGFR & NM_005228.4:c.2369C>T & NP_005219.2:p.Thr790Met \\
BRAF & NM_004333.5:c.1799T>A & NP_004324.2:p.Val600Glu \\
\hline
\end{tabular}


A KRAS G12C

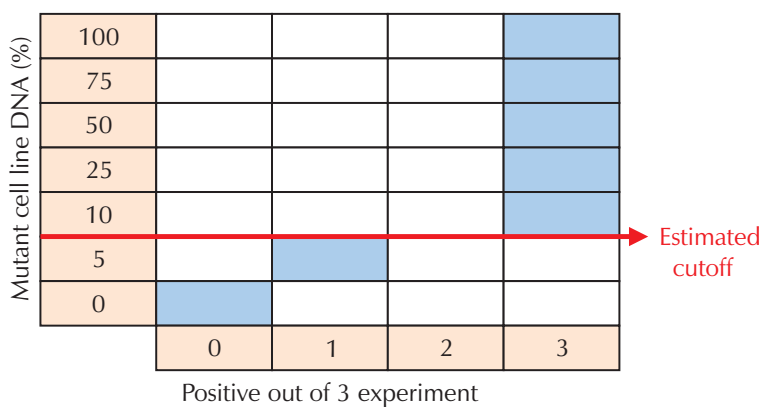

C EGFR T790M

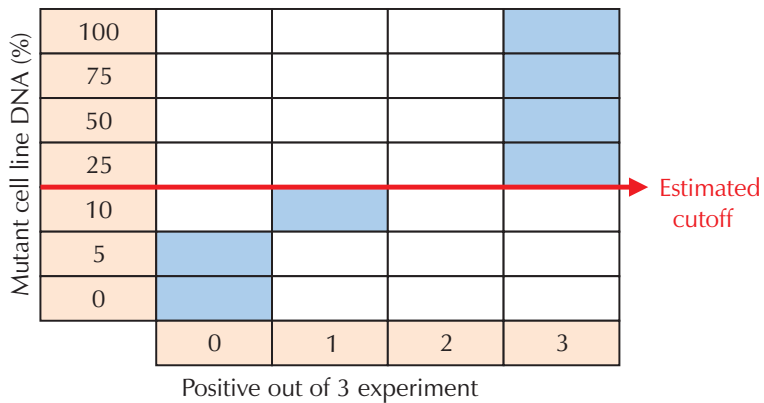

B EGFR exon 19 deletion

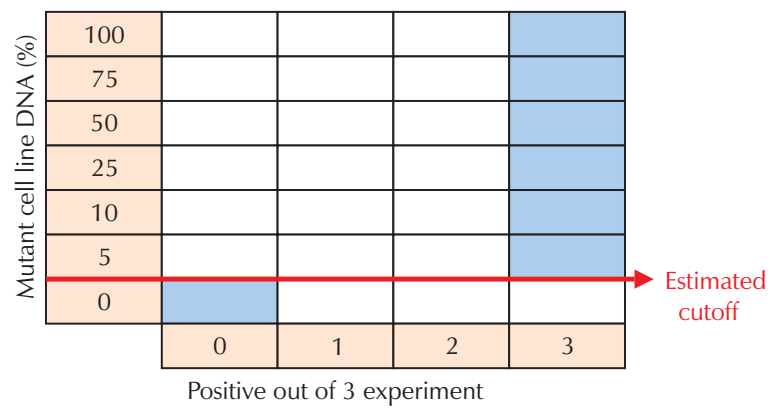

D BRAF V600E

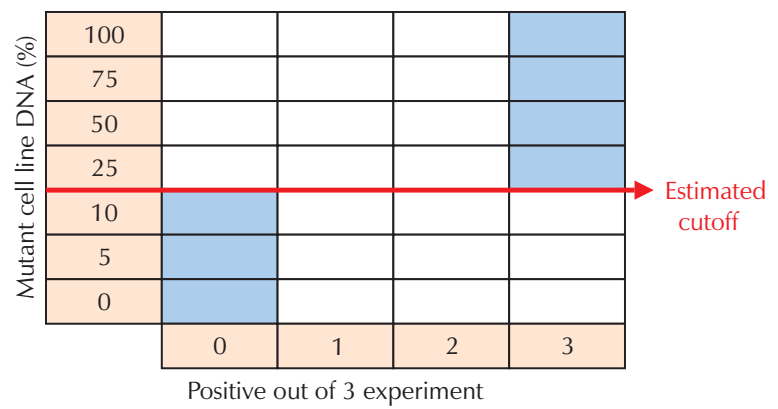

Fig. 1. Summary of the sequencing results. (A) KRAS G12C. (B) EGFR Exon 19 deletion. (C) EGFR T790M. (D) BRAF V600E.
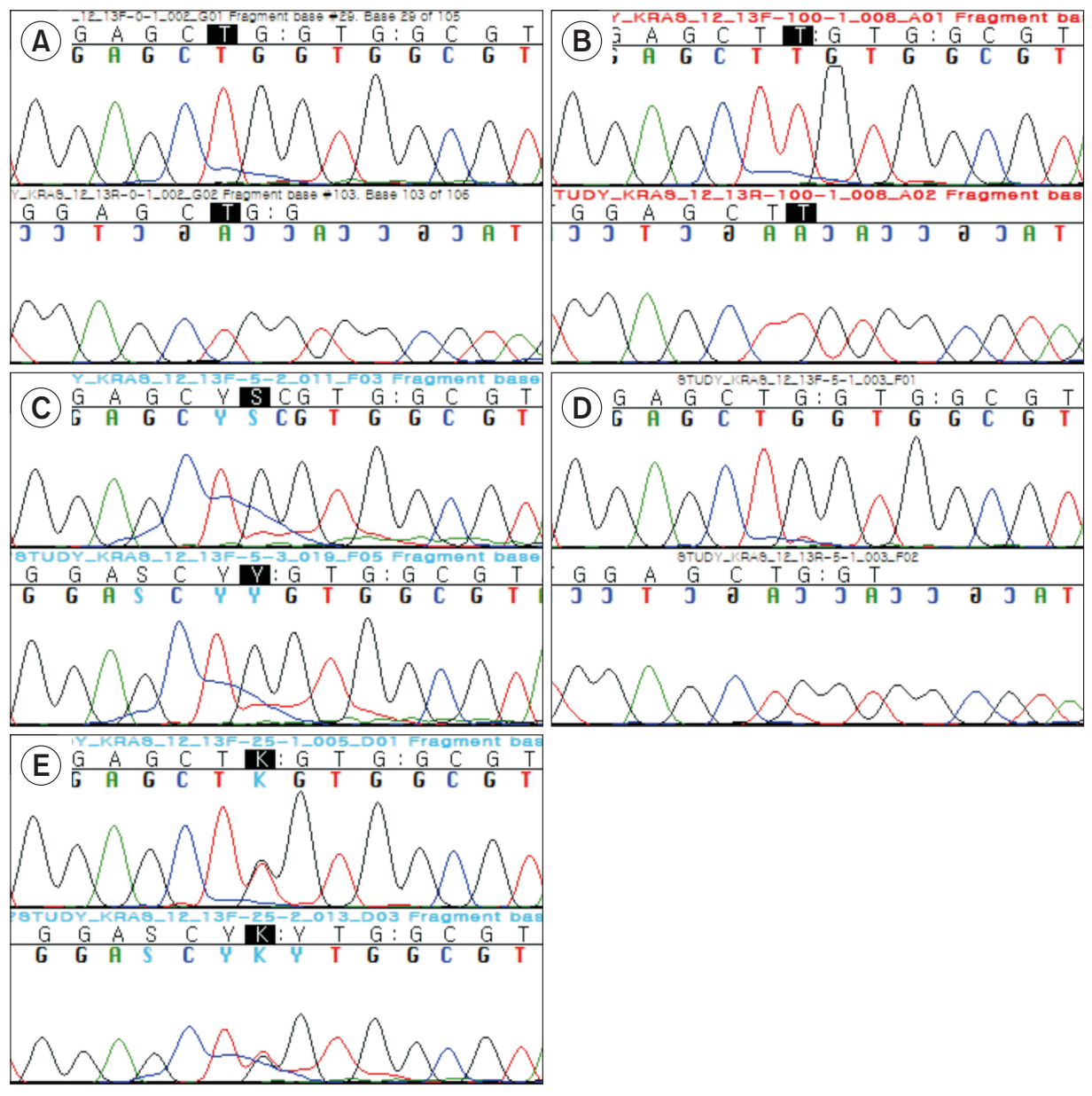

Fig. 2. Sequencing chromatogram of different ratio of KRAS G12C cell line DNA. (A) Mutant cell line DNA 0\%, determined as negative. (B) Mutant cell line DNA $100 \%$, determined as positive. (C) Mutant cell line DNA 5\%, determined as negative. (D) Mutant cell line DNA 5\%, determined as positive. (E) Mutant cell line DNA 10\%, determined as positive. 


\section{Sanger sequencing 및 희석 cutoff 결정}

제조한 희석 검체를 in-house developed custom primer 를 사용하여 ABI 3730 DNA Analyzer (Applied Biosystems, Waltham, MA, USA) 장비를 이용해 mutation hot spot에 대 한 Sanger sequencing을 실시하였다. 신뢰할 수 있는 결과 확 보를 위해 각 검체에 대해 실험을 3회 반복하여 결과를 취합하 였다. Sanger sequencing 결과는 Sequencher ver. 4.10.1 DNA sequence analysis software (Gene Codes Corp., Ann Arbor, MI USA)를 이용하여 판독하였으며, 판독자가 육안으로 sequencing chromatogram을 관찰하였을 때 variant peak가 명확히 구분되는 경우를 변이 양성으로 판정하였다. 2 명의 판독자 가 각각 판독하여 판독자에 따른 차이를 줄이고자 하였다. 각 희석 비율 검체별 3회의 실험 중 3번 모두 양성으로 판정되는 변이 세 포주 DNA의 최저 희석비율을 Sanger sequencing에서의 cutoff 로 결정하였고, 이를 비교하여 외부정도관리 양성 물질로 사용할 검체의 최소 조건을 규정하였다.

\section{결과}

실험결과, $K R A S \mathrm{G} 12 \mathrm{C}$ 의 경우 변이 세포주 DNA가 $5 \%$ 포함 된 경우 양성판정이 일관되지 않았고, 변이 세포주 DNA가 $10 \%$ 이상일 때 3회 실험 모두에서 일관되게 변이가 양성인 것으로 판 정되었다(Figs. 1, 2). EGFR exon 19 deletion의 경우 변이 세 포주 DNA 5\% 이상(Figs. 1, 3), EGFR T790M의 경우 변이 세포
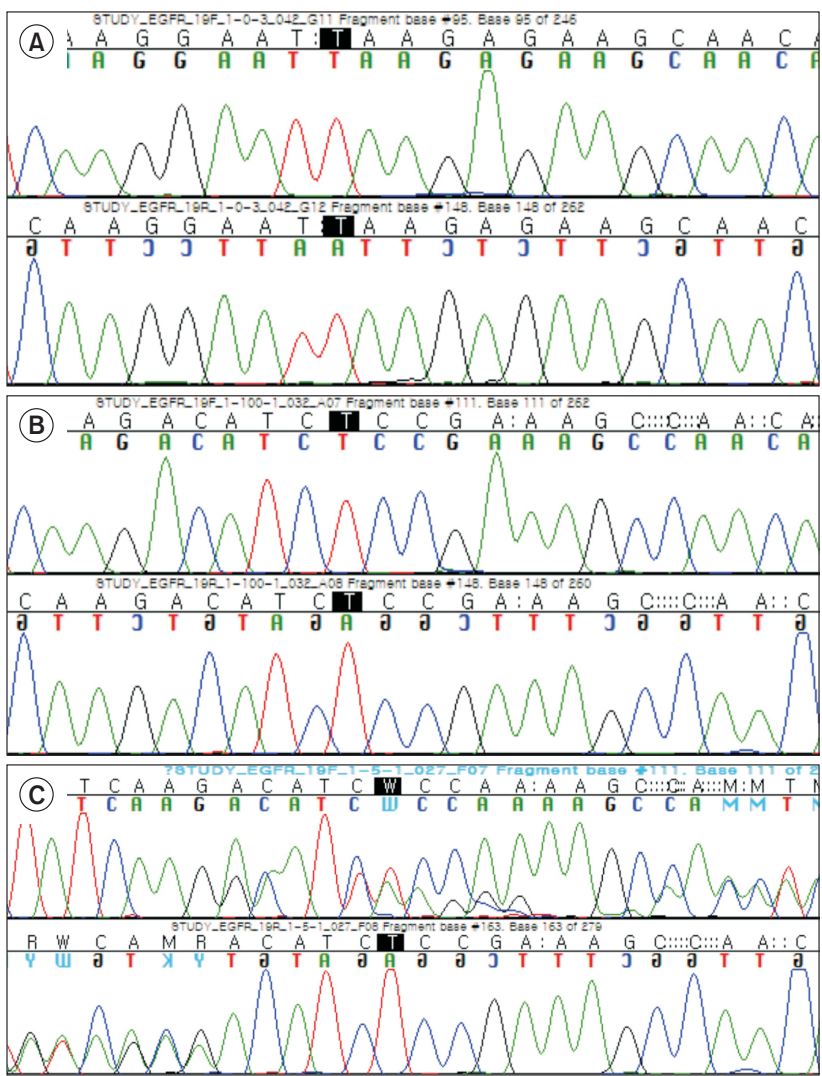

Fig. 3. Sequencing chromatogram of different ratio of EGFR exon 19 deletion cell line DNA. (A) Mutant cell line DNA 0\%, determined as negative. (B) Mutant cell line DNA $100 \%$, determined as positive. (C) Mutant cell line DNA 5\%, determined as positive.
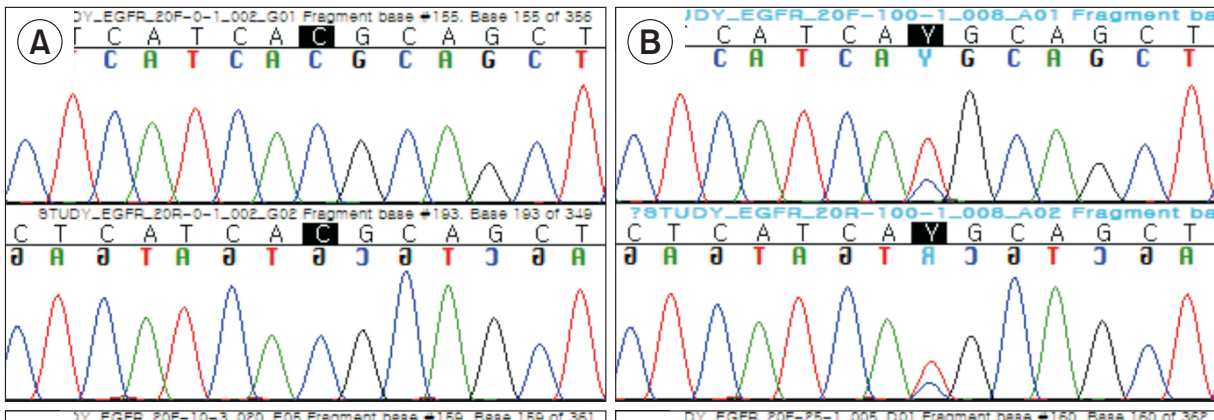

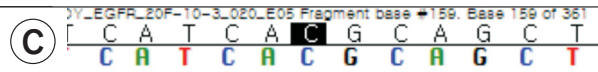
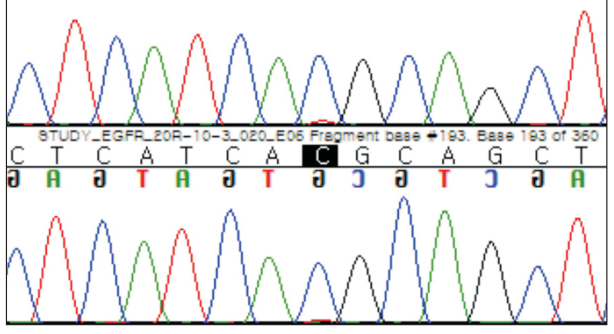
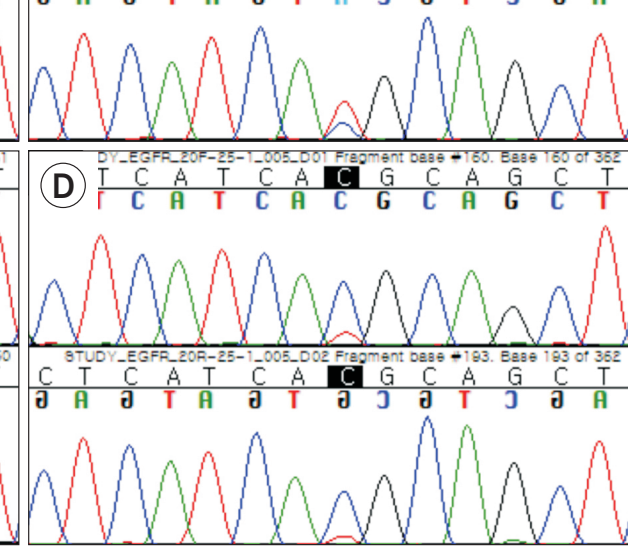

Fig. 4. Sequencing chromatogram of different ratio of EGFR T790M cell line DNA. (A) Mutant cell line DNA 0\%, determined as negative. (B) Mutant cell line DNA $100 \%$, determined as positive. (C) Mutant cell line DNA 10\%, determined as negative. (D) Mutant cell line DNA $25 \%$, determined as positive. 


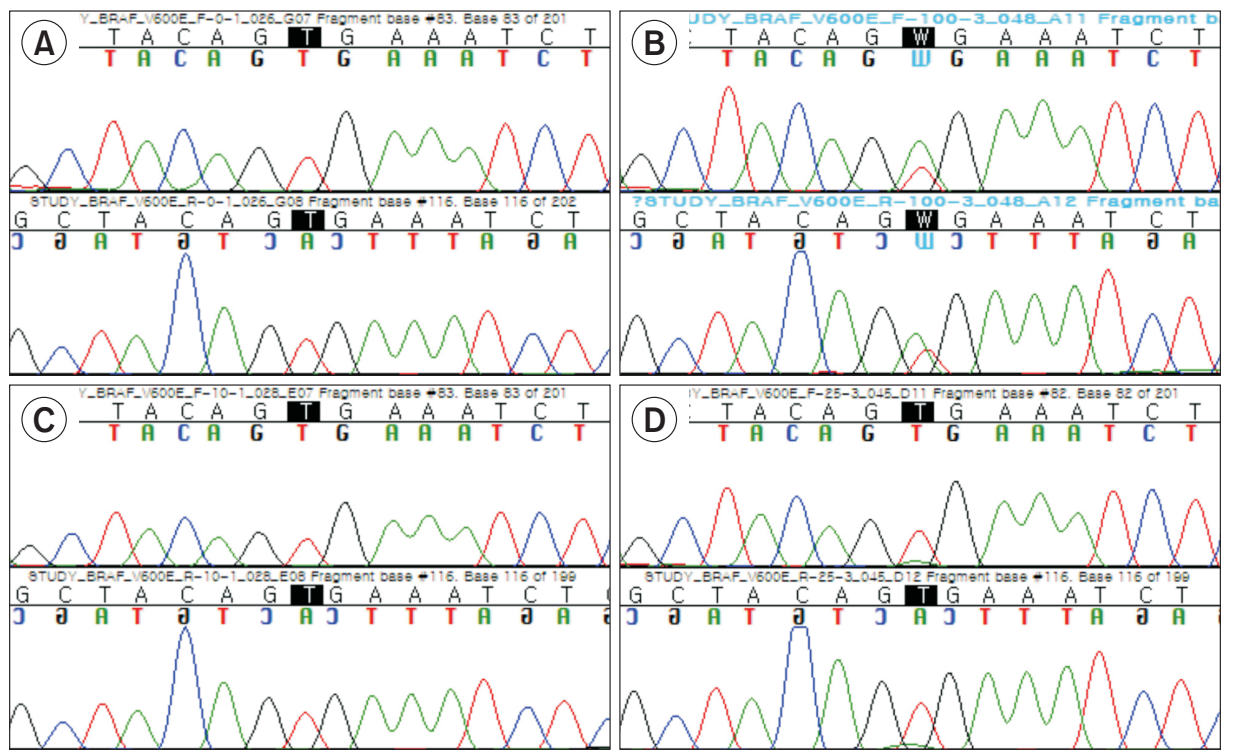

Fig. 5. Sequencing chromatogram of different ratio of BRAF V600E cell line DNA. (A) Mutant cell line DNA $0 \%$, determined as negative. (B) Mutant cell line DNA 100\%, determined as positive. (C) Mutant cell line DNA $10 \%$, determined as negative. (D) Mutant cell line DNA $25 \%$, determined as positive.
주 DNA $25 \%$ 이상(Figs. 1, 4), BRAF V600E의 경우 변이 세포주 DNA $25 \%$ 이상(Figs. 1, 5)의 농도에서 일관성 있게 3회의 실험 모두에서 target variant가 sanger sequencing을 통해 검출이 가능한 것으로 나타났다. 또한 EGFR T790M과 BRAF V600E의 경우 변이 세포주 DNA만을 사용한 검체에서 표적 변이의 mutant fraction이 $100 \%$ 가 되지 않았고, 대략적으로 $60 \%-70 \%$ 가량으 로 관찰되었다.

\section{고찰}

인간 유전자검사에서 외부정도관리물질로 사용할 수 있는 검 체에는 혈액이나 소변 등의 실제 환자 검체, 환자 검체에서 추출 된 DNA와 같은 물질, 배양된 세포, 인공적으로 합성된 DNA/RNA (synthesized DNA/RNA) 등이 있다[4]. 그러나 실제 정도관리에 사용하기에는 감염위험, 균질성, 확보 난이도 등의 문제로 국내에 서는 배양된 세포주가 주로 사용되고 있다.

일선 검사실에서는 고형 종양유전자 변이검사에 Sanger sequencing, pyrosequencing, real-time polymerase chain reaction 등을 사용하고 있는데, 본 연구에서는 검사실에서 사용 하는 모든 검사방법에 외부정도관리 양성 물질로 이용될 수 있도 록 하기 위하여 이 중 가장 민감도가 낮다고 알려져 있는 Sanger sequencing을 기준으로 하여 검체 조건 설정방법을 정하였다.

KRAS G12C와 EGFR exon 19 deletion의 경우, 본 연구에 서 변이 세포주 희석비율의 cutoff를 $10 \%$ 로 설정하였을 때, 3 회 의 실험 및 2 명의 판독자의 판독결과가 일관되게 변이 양성으로 판정될 수 있었다. 그러나 EGFR T790M과 BRAF V600E의 경우,
본 연구에서 변이 세포주 희석비율이 $25 \%$ 인 경우가 cutoff로 관 찰되었다. 그러나 EGFR T790M 검사에 이용한 세포주와 BRAF $\mathrm{V} 600 \mathrm{E}$ 검사에 이용한 세포주 자체의 mutant fraction이 $100 \%$ 가 아니라 60\%-70\% 가량인 점을 고려하였을 때 실제로는 변이 DNA의 proportion이 $10 \%$ 이상인 경우에 Sanger sequencing 을 통해 해당 변이의 검출이 가능하였다고 판단할 수 있었다. 문헌 에 따라 다소 차이가 있으나, Sanger sequencing의 경우 검출한 계는 $10 \%-20 \%$ 내외인 것으로 알려져 있어[5,6], 본 연구의 결과 가 기존에 알려진 바를 따르는 것을 알 수 있다. 따라서 외부정도 관리 양성 물질 제조 시 mutant proportion이 $10 \%$ 이상이 되도 록 변이 세포주 DNA와 야생형 세포주 DNA를 혼합하여야 한다.

또한 본 연구의 경우와 같이 시판되는 세포주의 경우에도 mutant allele의 백분율이 $100 \%$ 가 아닐 수 있으므로, 고형 종양 외부정도관리용 양성 검체를 제조하기 위한 희석 배수를 결정하기 전에 사용할 세포주의 대략적인 mutant proportion을 사전에 확 인하여야 검출한계 미만의 검체가 제조되어 잘못된 외부정도관리 검체가 배포되는 것을 막고 원활한 외부정도관리 프로그램 운영을 할 수 있다.

본 연구의 한계는 mutant proportion의 조절만으로는 환자 검체의 완벽한 재현은 가능하지 않다는 점이다. 고형 종양 외부정 도관리사업의 경우, 종양조직 또는 종양세포를 함유하고 있는 흉 수 등의 체액 검체를 이용한 유전자검사를 대상으로 한다. 조직 검 체의 경우, 신선한 검체뿐 아니라 포르말린 고정 파라핀 포매조직 절편(formalin fixed paraffin embedding, FFPE)에서 추출된 DNA 또한 유전자검사의 대상이 될 수 있다. FFPE 검체의 처리과 정에서 파라핀 제거, DNA를 추출할 종양이 의심되는 부위의 선택 
등 여러 단계가 추출된 DNA의 질과 양에 영향을 미친다[7]. 본 연 구에서 고안한 세포주 DNA의 혼합방식을 이용해 생산된 정도관 리물질로는 이러한 조직 검체의 처리과정에서 발생할 수 있는 검 사오류를 반영하기 힘들다는 한계점이 있다.

\section{감사의 글}

이 연구는 대한임상검사정도관리협회의 2019년 학술연구비 지 원으로 수행되었다(과제번호: 2019-08).

\section{ORCID}

Jinyoung Hong https://orcid.org/0000-0001-8855-7900

Ji Hyun Kim https://orcid.org/0000-0003-2424-2074

Seungman Park https://orcid.org/0000-0003-2123-3711

Sang Gon Lee

Woochang Lee

Sail Chun

Won-Ki Min https://orcid.org/0000-0002-4672-5811

https://orcid.org/0000-0003-3956-6397

https://orcid.org/0000-0002-5792-973X

https://orcid.org/0000-0002-5158-2130

\section{REFERENCES}

1. Li MM, Datto M, Duncavage EJ, Kulkarni S, Lindeman NI, Roy S, et al. Standards and guidelines for the interpretation and reporting of sequence variants in cancer: a joint consensus recommendation of the Association for Molecular Pathology, American Society of Clinical Oncology, and College of American Pathologists. J Mol Diagn 2017;19:4-23.

2. The Food and Drug Administration. Companion diagnostics. https://www.fda.gov/medical-devices/vitro-diagnostics/ companion-diagnostics (Accessed September 17, 2020).

3. Mitsudomi T, Kosaka T, Endoh H, Horio Y, Hida T, Mori S, et al. Mutations of the epidermal growth factor receptor gene predict prolonged survival after gefitinib treatment in patients with non-small-cell lung cancer with postoperative recurrence. J Clin Oncol 2005;23:2513-20.

4. Clinical and Laboratory Standards Institute. Design of molecular proficiency testing/external quality assessment; approved guideline. 2nd ed. Wayne (PA): Clinical and Laboratory Standards Institute, 2013.

5. Tsiatis AC, Norris-Kirby A, Rich RG, Hafez MJ, Gocke CD, Eshleman JR, et al. Comparison of Sanger sequencing, pyrosequencing, and melting curve analysis for the detection of KRAS mutations: diagnostic and clinical implications. J Mol Diagn 2010;12:425-32.

6. Davidson CJ, Zeringer E, Champion KJ, Gauthier MP, Wang F, Boonyaratanakornkit J, et al. Improving the limit of detection for Sanger sequencing: a comparison of methodologies for KRAS variant detection. Biotechniques 2012;53: $182-8$.

7. Snow AN, Stence AA, Pruessner JA, Bossler AD, Ma D. A simple and cost-effective method of DNA extraction from small formalin-fixed paraffin-embedded tissue for molecular oncologic testing. BMC Clin Pathol 2014;14:30. 